\title{
The Role of the Protestant Church in the us Refugee Resettlement Program during the Early Cold War Era
}

The Methodist Case

Hiromi Chiba

In Europe, at the end of World War II, there were approximately eleven million refugees, known collectively as displaced persons (DPs), living outside their nations' boundaries. About one million of these were resettled overseas during the next several years. Specifically, under the Displaced Persons Acts of 1948 and 1950, the United States accepted over 400,000, more than 70 percent of who were refugees from the USSR and Eastern Europe. The Refugee Relief Act of 1953 and amendments to it also authorized the admission to the Us of another 200,000 refugees from war-torn Europe and escapees from Communistdominated countries (Daniels 2004: 98, 109-112, 125-127; US Displaced Persons Commission (DPC) 1952: 243; Dinnerstein and Reimers 2009: 118-119; Holman 1996: 5). Thus, by the early 1950s, the groundwork had been laid for the granting of asylum to millions of additional refugees from various parts of the world in the years to follow.

The early postwar years were also a time when the active involvement of religious agencies, especially Christian churches, in the resettlement program originated and evolved in America. Indeed, refugee relief and resettlement, as part of foreign aid, was an instrument of America's Cold War strategy, since escapees from the 'oppressed' Eastern bloc to the 'free' world were perceived by the West as political and ideological 'assets' which had propaganda value both at home and overseas (Nichols 1988: 79-87; DPC 1952: 238-240). Recognizing this role, recent scholarship has highlighted the integration of religious agencies into Cold War diplomacy, where the superiority of the American Way of Life was promoted (Schäfer 2006: 175-193). At the same time, the humanitarian and missionary impulses of American churches, which were at work independent of the diplomatic cause, provided the driving force for their relief activities. While the state's role was imperative in creating a legislative framework, church groups played a leading part in arranging and implementing resettlement, frequently lobbying and negotiating with government. This

Originally published in Exchange 43 (2014) 9-28.

(C) HIROMI CHIBA, 2016 | DOI 10.1163/9789004326156_005

This is an open access chapter distributed under the terms of the CC-BY-NC License:iromi Chiba - 9789004326156 
crucial role of churches in refugee resettlement deserves closer academic attention.

This contribution will first explore how the us refugee resettlement program developed, focusing on non-governmental initiatives, and how the Protestant church became involved (Robert 1997: 382 ). ${ }^{1}$ I will secondly examine the visions and missiology behind the churches' participation in the program, through a focus on the case of the Methodist Church, one of the leading denominations affiliated with the Church World Service (cws), the Protestant interdenominational body responsible for refugee resettlement. In so doing I will attempt to assess the churches' relationship to issues of ethnic tolerance and cultural diversity, and its contribution to this internationalist endeavor. As Dana L. Robert pointed out, Christian missions have frequently been analyzed in relation to American nationalism and imperialism (Robert 1997: 382). ${ }^{2}$ Such critical analyses, while they have strengths, should not hinder us from studying American missions in their own right and from seeking balanced evaluation of the roles they have played in internationalism. This is an area of research that awaits further historical scholarship.

\section{The Early Development of the us Refugee Resettlement Program and the Involvement of Churches in It}

\subsection{The Displaced Persons Acts of 1948 and $195^{\circ}$}

The great majority of DPs in Europe were repatriated to their own countries soon after the war. Many, however, were unable or unwilling to return to their homelands due to such reasons as the reshuffling of national boundaries, opposition to Communism, or fear of standing trial for collaboration with the Nazis, while other refugees continued to arrive from the east (Daniels 2004: 98; Dinnerstein and Reimers 2009: 118; Genizi 1993: 20). DPs were forced to endure deplorable living conditions in hundreds of DP camps

1 This contribution, while focusing on the Methodist case, employs the term 'the Protestant church', since it discusses the general attitudes and policies of the Protestant church in the us at large, as expressed in the statements and the actions of the Church World Service as well as the National Council of the Churches of Christ in America, which coordinated the Protestant refugee relief efforts there.

2 Robert (1997: 383) went on to note, 'Unexamined but equally important is the contribution made by missions to internationalism.' 
managed by the United Nations Relief and Rehabilitation Administration, which was replaced by the International Refugee Organization in 1948.

While the American public at the end of the war remained largely reluctant to admit more immigrants, ${ }^{3}$ President Truman took a first step to alleviate the crisis by issuing a directive on 22 December 1945 that gave preference to refugees within us immigration quotas. This directive began the practice of having voluntary agencies (VoLAGs) assume responsibility for resettling refugees, and about 40,000 people benefited from the directive (Daniels 2004: 103; Dinnerstein 1982: 113-114; Gordon 1996: 335; DPC 1952: 7). ${ }^{4}$ On 16 August 1946, Truman also declared his intention to seek the approval of Congress for special legislation authorizing entry into the us of a fixed number of D PS (Genizi 1993: 68). In the following weeks, support for the President's proposal was publicly expressed by the influential Catholic weekly, Commonweal, and the Federal Council of Churches of Christ in America, the nation's largest body of Protestant churches. In addition, Life magazine, in its 23 September 1946 issue, 'became the first national journal of general interest to urge a new policy' to admit DPs (Dinnerstein 1982: 118). ${ }^{5}$

During the subsequent two years before the enactment of the Displaced Persons Act of 1948, various groups sought to influence government policy. In particular, Jewish advocates played a key role. In late 1946, American Jewish leaders from the American Jewish Committee (AJC) and the American Council for Judaism (ACJ) started working to bring 100,000 Jews to the Us. For tactical reasons, the AJC's goal was legislation to permit the admission of 400,000 refugees, since Jews constituted 20 to 25 percent of European DPs. It was understood, 'it would be easier to get Christian support if the program demanded the admission of 400,000 DPs' without mentioning the Jewish DPS at all. The admission of about a half of the estimated 800,00o non-repatriable DPs remaining in Germany and Austria was also considered to be America's 'fair share' (Genizi 1993: 69-70; Dinnerstein 1982: 117-123).

Following intensive consultations and campaigns to gain support from non-Jewish circles, including prominent Senators, Congressmen, business and labor leaders, and especially Protestant and Catholic church leaders, the AJC and ACJ leaders established in December 1946 the Citizens Committee on Displaced Persons (CCDP), which 'gradually became an effective lobby on

3 According to a Gallup poll in December 1945, when asked whether more European immigrants should be admitted than before the war, or the same number, or fewer, 5 percent said more, $3^{2}$ percent said the same, 37 percent said fewer, 14 percent none at all, and 12 percent had no opinion (Dinnerstein 1982: 114).

4 While apathy dominated the Catholic and Protestant circles, Jewish DPs received two-thirds of the visas issued under this directives as of 30 June 1947 (Genizi 1993: 37).

5 For other press opinions, see DPC 1952: 9-11. 
behalf of DP legislation' (Genizi 1993: 72). The help of Christian leaders was crucial in persuading the public to support the DP bill, which was introduced to Congress in April 1947, and 'collective nonsectarian efforts' led by the CCDP gradually changed the mood of the public and Congress (Genizi 1993: 203). ${ }^{6}$ Consequently, by 1948, 'almost every major American organization, except for the Daughters of the American Revolution, eventually endorsed the goals of the CCDP'(Dinnerstein 1982:127;Wyman1998:194-195).The CCDP thus proved 'the catalyst' for cooperative humanitarian action (Dinnerstein 1982: 267).

In June 1948 the DP Act was finally enacted, which, despite its restrictions and discriminatory provisions against Jews (Smith 1966: 45), became 'a landmark in the history of American immigration policy' (Dinnerstein 1982: 182) by legally recognizing for the first time the country's responsibilities for housing some of the world's refugees and by establishing machinery for processing refugees into the country. It also 'paved the way for the more generous and understanding refugee relief acts of subsequent years' Dinnerstein 1982: 280 ). Furthermore, amendments in 1950 eliminated many of the discriminatory provisions of the original act and extended it to run for two more years (Daniels 2004: 109; DPC 1952: 7, 37-39).

One of the main features of the DP Acts was the establishment by Congress of the United States Displaced Persons Commission (DPC), which operated from August 1948 to August 1952. It was the first federal agency responsible for supervising and coordinating refugee resettlement. The most prominent aspects of the DP Acts, however, were the provisions that allowed various volags to issue 'assurance' of housing and employment, to guarantee that the DPs admitted to the us would not become 'public charges', and to oversee refugee resettlement on a case-by-case basis. Under the DP Acts (and also the Refugee Relief Act of 1953), refugees could not be admitted without assurance from a sponsor, and this system necessitated close cooperation between the DPC and the vOLAGS. By the end of the DP program, the DPC had accredited nineteen volaGs, representing religious, ethnic, and welfare interests, and almost 9o percent of the more than 300,000 'assurances' of support filed with the DPC were submitted through the volaGs, not by individuals (Daniels 2004: 107-108; Holman 1996: 5; DPC 1952: 268-271). Thus, through sponsorships, the volAGs 'pumped life-blood into the program and got it going' (DPC 1952: 271). As the DPC's final report stated, the volAGS 'performed services in all the major operations of the program except those relating to security analysis and eligibility determinations', which were the

6 According to Genizi, 'church leaders after 1947 showed sustained interest in the issue, having learned that 80 percent of the DPs were Christians,' although Catholics and Protestants had opposed any relaxation of the restrictive immigration laws during the 1930s. 
government's responsibilities, and these private groups, having nationwide networks of affiliates at local levels, 'made an inestimable contribution in this joint effort'. The report concluded, 'The success of the resettlements under the Act are [sic] in large proportion due to their efforts, planning and follow-up. This was an experiment in new relationships between Government and private agencies' (DPC 1952: 267, 294).

Among volags, religious bodies carried the greatest load. Particularly, more than two-thirds of the over 400,000 persons admitted under the DP program were resettled by only four agencies: as of 30 June 1952, the National Catholic Welfare Council (NCWC) settled 151,694; the CWs, representing twenty-three agencies, sponsored 51,010; the National Lutheran Council (NLC) placed about 42,00o; and the United Service for New Americans (USNA), a Jewish group, settled 38,524 . These figures roughly reflected the makeup of the immigrants under the DP Acts: 47 percent were of the Catholic faith; 35 percent of the Protestant and Orthodox faiths; 16 percent of the Jewish faith, and 2 percent of other faiths (DPC 1952: 248, 267-270, 275-294).

Other important players in the DP program were State DP Commissions or Committees organized in thirty-six states. These were formally established governmental bodies, but consisted of representatives from religious and other VOLAGs, business, labor, consumer groups and leading citizens, who served on a voluntary basis, as well as officials from state and local government agencies. The combination of their official position, their voluntary character and public-private composition was an experiment in 'new ways of accomplishing national objectives' (DPC 1952: 307). Religious agencies, through their participation in the State Commissions, thus played an important role in developing public opinion concerning the program, enlisting local help, and smoothing difficult resettlement situations (DPC 1952: 294-309).

In sum, according to the DPC's final report, 'In Europe, in Washington, and more importantly, in the local communities throughout the length and breadth of the United States, agencies of all faiths were brought closer together, through the resettlement program and the various State and local commissions and committees' (DPC 1952: 275-276).

Finally, the responses of the CWs and Protestant churches toward the DP Acts need to be noted. The cws was established in May 1946 to unify the various relief and reconstruction efforts of American Protestant agencies, and took over in 1947 the refugee program from its predecessor, the American Christian Committee of Refugees, which had operated since 1934. Under the DP Acts, CWs took responsibility for resettling all the non-Lutheran Protestant and Eastern Orthodox groups (DPC 1952: 276; Genizi 1993: 39). The first phase (1948-1949) of its work was 'characterized by confusion, inefficiency, and lack of moral 
and financial support by the denominations', but the cws and its affiliated denominations 'gradually overcame their earlier shortcomings', and together made 'impressive' achievements (Genizi 1993: 146-147). For example, one of the cws's cooperating agencies, the Methodist Committee for Overseas Relief (MCOR), which represented the Methodist Church in the field of overseas relief, aided in the resettlement of 5,122 DPs under the DP Acts (MCOR 1954: 11). The church also 'assumed a moral responsibility for guiding the New Americans through five years after their arrival' (MCOR 1953a: Appendix E, 1). Additionally, the transfer of the cws's services in Europe to the World Council of Churches (WCC) in July 1950 and its merger in January $195^{1}$ with the National Council of the Churches of Christ in America (NCC), the nation's largest Protestant body created in 1950, improved its efficiency (Genizi 1993: 146-147).

\subsection{The Refugee Relief Act of 1953}

The major us response to the ongoing refugee problem after the expiration of the DP Acts in $195^{2}$ was the Refugee Relief Act of 1953, occasionally known as the 'Church Bill' due to the active support received in Congress from religious refugee agencies (Nichols 1998: 86).

In March 1952, as the DP program drew to an end, the NCC issued a statement urging the continuation of the Us refugee resettlement program, and expressed its strong opposition to any Congressional action which would hinder the international refugee resettlement operations or the participation of the us in them. The statement then criticized the government's 'piece-meal' measures, and emphasized the importance of adopting enlightened immigration legislations that would conform to the principles of democracy and human rights, and would remove 'all discriminatory provisions based upon considerations of color, race or sex.' The NCC thus demanded immigration measures to achieve 'a just and durable peace' (NCC 1952).

The Refugee Relief Act essentially continued many of the programs of the DP Acts, authorizing the issuance of 214,000 visas over and above the quota system before 31 December 1956, and a total of 189,025 persons entered the Us under the act. Most of the visas went to Europeans fleeing from Communism, but several thousand were provided for Asians, including refugees of the Chinese Revolution (Daniels 2004: 125; Gordon 1996: 335-336; Nichols 1998: 84-87). With no DPC under this act, its administrative responsibility was transferred to regular immigration channels. Moreover, volAGs, mainly churches, continued to play a vital role in securing resettlement opportunities, receiving and assisting refugees on arrival and assuming responsibility for all aspects of their integration into American community life (MCOR 1953c: 31-33). According to a CWS report, the numbers of refugees settled under the act by NCWC, 
CWs, NLC, Hebrew Immigrant Aid Service/USNA were 40,000, 30,000, 15,796, and 3,500 respectively (Migration Services Policy Committee 1958: Statistical Appendix 5).

While the cws, an organ of the NCC, continued to serve as a coordinating agency, denominations were responsible for the actual resettlement of refugees. The Immigration Services of cws was a 'link' between refugee and sponsor, as well as between the WCC and the denominations, and its Welfare Section provided advice and assistance to churches and individual their problems with refugees, even offering psychological care (cWs 196ob; cWB 196oc). Within each denomination, not the national church agency, but the local church which sponsored the immigrant or had sponsors among its members, was expected to take the basic responsibility for integration (MSPC 1960).

In the case of MCOR, which accepted responsibility for sponsoring 5,000 refugees, its promotion activities included various methods such as holding one-day seminars in many areas with the help of the respective bishops and district superintendents, making direct-mail appeals to church leaders, appointing area or conference committees to give local guidance, and extensive use of the church press. MCOR's publicity personnel, who had witnessed the plight of refugees by visiting refugee camps, also made energetic speaking tours, presenting the program to local congregations nationwide. Consequently, despite the initial slow reaction, the responses of the churches more than matched the needs of the program. MCOR secured sponsorships for a total of 8,393 persons between August 1953 and December 1956, and 4,350 persons (the largest number of all the denominations in the cws) actually arrived in America (MCOR 1956: 5; MCOR 1957: 6, 10; MCOR 1958).

With the Refugee Relief Act and the supplemental refugee laws, the us refugee program, though it was characterized by a series of ad hoc bills and executive actions (Nichols 1998: 84), continued through the 1950s, and the basic pattern of the active participation of churches set under the DP Acts also continued. In its 1957 General Assembly, the NCC rejoiced at the contribution of its member churches to the resettlement program during the past decade. It then urged the government to continue its refugee relief, and recorded 'its support of all such governmental and intergovernmental refugee measures motivated by considerations of justice, mercy and sound mutual assistance' (NCC 1957). The NCC also called upon its member churches to 'give public approval' to the government 'in its recognized obligation to support effectively the United Nations programs for refugees without regard to percentage of support by other governments' (NCC 1957).

Moreover, while the UN designated July 1959-June 1960 as the World Refugee Year, the General Board of the NCC adopted at the year's mid-point a 
resolution advocating more persistent government action to serve the urgent needs of the refugees. The resolution urged the NCC member churches to 'encourage the members of the Congress to act responsibly for the problems of refugees.' It also encouraged the churches to support through Congress a number of measures including the adoption of permanent legislation providing for the non-quota visa admission of 10,00o refugees and escapees annually, an increase in active cooperation with international agencies serving refugees, and the adoption of a fairer and non-discriminatory immigration and naturalization law (NCC 1959).

Furthermore, in February 1960, the Board of Managers of cws sent a telegram to the President urging additional refugee legislation (CWs 196od). An MCOR report of the same month also complained, 'We are agreed on what we want and ought to do. We have the apparatus ready for the operation. Only enabling legislation is missing and the longer we have to wait for it, the more we lose in the promotional effect of the World Refugee Year' (MCOR 196ob).

Church leaders thus pressed for official actions, since governmental support and legislative framework for liberalizing the immigration policy were imperative. On the other hand, the government was eager to obtain the grass-roots assistance of churches in the context of the massive expansion of the federal government after World War II (Nichols 1998: 76, 98-99; Schäfer 2006: 176-177). One might argue that churches were incorporated into the government's Cold War strategies, but it is also true that churches often took the initiative in refugee resettlement and sought to expand their sphere of influence, as the next chapter reveals. Axel R. Schäfer also noted, 'While the state drew upon the resources of religious entities, it also safeguarded their organizational autonomy and effectively sanctioned their faith-based practices' (Schäfer 2006: 176). According to one analysis in 1953, 'fully 9o percent of postwar relief was provided by religious agencies' (Elias 1953: 30-34, cited as in Nichols 1998: 68). With such a dominant role, ethnic and religious groups and their vOLAGS responsible for refugee settlement had become by the 196os 'the major nongovernmental groups influencing American immigration policy' (Reimers 1985: 12).

As to the financial ties between church and state, the Escapee Program under the Mutual Security Act of 1951 initiated direct government contracts with the volags including religious bodies, for refugee services abroad (Nichols 1998: 86, 208). However, it was the Cuban refugee crisis of 1960-1961 that marked a drastic change in the government's refugee policy, ushering in 'new federal funding streams for the resettlement work of religious agencies' (Schäfer 2006: 181). Thus, 'the device of a contractual partnership' emerged 'that would, in time, be institutionalized between the federal 
government and the private agencies in the domestic resettlement of refugees' (Zucker 1982: 156).

\section{The Visions and the Missiology: The Methodist Case}

\subsection{Refugee Relief as a Living Testimony to the Power of Faith}

This section, through a focus on the Methodist experience, will explore the visions and missiology of Protestant churches that motivated their efforts to assist refugees. MCOR, established in 1940, was the first American denominational relief committee (MCOR 1942: 2), and its task 'focused on studying the most urgent needs and pressing problems around the world, reporting these needs to the local churches, and administering the necessary funds to 'the least of these' through partner agencies and ecumenical networks' including cws and WCC (UMCOR 2009; Lee 1958: 20). Its mission was to 'be ever ready to fulfill the injunction' of Christ (MCOR 196oa: 2), to feed the hungry, clothe the naked and care for the homeless, which was considered to be 'an essential part' of Christian faith (MCOR 196ob: 5).

During World War II, as the role of the government expanded in America, a sense of crisis and an urge to exert greater influence over society grew in the Methodist Church, 'the leading Protestant denomination of the richest country on earth' (MCOR 1942: 2). In justifying the cause of overseas relief, a statement of MCOR in July 1942 argued:

[T] his [an emphasis on overseas relief] is necessary in order to maintain the proper place of the Church in this confused age... Greater political, economic, and social changes are in process around us than have ever been witnessed on earth before. Government-our Government-is taking into its hands in an unprecedented way the lives of the people. Recreation, education, social welfare, medical care-are being lifted out of the hands of private agencies and being fostered by governmental or semi-governmental bodies. What is to become of the Church in this jostling world? Unless the Church seizes the day of its opportunity in some competent and adequate way, it may be rudely pushed aside as irrelevant or at most negligible (MCOR 1942:3). [emphasis in the original]

The document went on to stress that the church, 'as the Church of the Living God, the habitation of the Mighty Spirit,' should 'prove daring and sacrificial in the great day,' and 'create the spirit of goodwill' (MCOR 1942: 3). An MCOR report in the following year also indicated its readiness to undertake a postwar 
reconstruction program (MCOR 1943: 2). Before the end of the war, MCOR was thus ready to embark on refugee relief programs.

After the war, an MCOR document of October 1948, referring to the Methodist Church's responsibility to sponsor 5,000 DPs, argued that the government, 'however large its investments under the Marshall or other plan,' could not meet the needs of 'the time of crisis beyond all precedent,' since it was 'neglectful of the individual' and lacked 'the personal touch'. Foreign aid by a church group, by contrast, was 'more effective' and 'motivated solely by love for mankind', and carried 'a spiritual force' that did 'not exist in the dispensing of relief by Governments.' Perceiving refugee relief as an area of vital importance in which the church had a special mission, MCOR called on the church to 'fill its place in the plan of God and the needs of men' (MCOR 1948b: 5 ). In a changing world in which competing secular forces, particularly government, expanded their spheres of operation, MCOR asserted the Christian church's unique place and spiritual mission.

The Cold War tone was evident in MCOR and NCC documents with their references to 'the victims of totalitarian tyranny' (MCOR 1952b: 3; NCC 1952:1). At the same time, a strong humanitarian impulse undoubtedly provided the driving force for the churches' sponsorship of refugees. An MCOR report of $195^{2}$ stated, 'Seldom have the Christian churches of America had a clearer opportunity to show their faith and power... We are persuaded that our Methodist Church has been engaged in a piece of glorious Christian idealism-humanitarianism of the highest order' (MCOR 1952a), which was 'a living testimony' to the power of faith (MCOR 1952b: 5 ). Another report in $195^{2}$ rejoiced over 'the greatest blessing' of seeing people 'beaten down by years of camp life and dependence upon others' slowly regaining self-confidence. The author closed the report by focusing on 'the way of Love' as Christ's way (MCOR 1953c: 12-14).

'The Good Samaritan' was the Biblical example frequently mentioned in MCOR documents as evidence of Christian principles in support of overseas relief. Summarizing the pressing needs in various parts of the world and the work of MCOR during the last four years, its report in 1948 asserted, 'From them all, the helping hand of the Good Samaritan, who once rescued a stranger and an alien, cannot yet be withdrawn.' Additionally, regarding refugee resettlement, the report declared, 'The call for Christian overseas relief has not thus died away during these four years, but rings out louder than four years ago' (MCOR 1948a: 1).

Likewise, in a 1958 article, 'Is the Good Samaritan Outmoded?', Gaither P. Warfield, the Director of MCOR from $195^{2}$ to 1966, who also served as vice-chairman of cws and was the American representative on Interchurch Aid, an organ of wCC, affirmed that Christian charity still had a place in a 
world where government and large secular organizations spent millions annually to succor the needy. According to Warfield, 'Christian charity says that needy people, even panhandlers, are personalities, loved by God and precious in his sight,' and 'the concern for the individual and necessity to recognize his value at all times is the distinctive mark of Christian giving' (Warfield 1958: 2).

Warfield also argued against those citizens who hoped to 'buy friendship for the USA by shipping surplus commodities to underfed peoples' (Warfield 1958: 1). While providing us surplus food for distribution abroad under the Agricultural Act of 1949 and the 1954 Food for Peace legislation was evidently a part of the Us Cold War programs (Schäfer 2006: 181), Warfield attempted to distinguish between such foreign policy and Christian giving, even stating that the former approach was 'futile'. He stressed the disinterested nature of church work as follows: 'When we aid those who are needy, hoping to help them to become self supporting and independent, then indeed we have a good chance of success. This result is our ample recompense' (Warfield 1958:1).

Meanwhile, church leaders were not so naïve as to disregard the political meaning of us foreign aid including refugee relief, but worked closely with government in order to pursue their religious cause. In 1957, an MCOR report on the Methodist program under the Refugee Relief Act affirmed, 'We have helped our country to assert once more its position of international leadership.' It added, however, 'An act of Government alone cannot provide the heart, which makes all the difference in a large scale resettlement program and which is missing in some migration schemes' (MCOR 1953b:1). In other words, claiming its special spiritual role, the church leaders accepted the 'complementarity' of religiously based programs to government policies (Nichols 1998: 81). The report stated that the refugee problem had become 'a chronic disease of the present day's world in unrest', and it was 'unthinkable' for them 'to stay out', since 'such a program would be a most worthy and stimulating project for the life of the church' (MCOR 1953b: 5).

Relief programs were thus conducted in a framework of missionary enterprise to manifest God's love by practicing good neighborliness. It was hoped that MCOR's 'humble efforts to succor the needy' would 'at the same time create a desire to learn more about the Lord' whom they served (MCOR 1955: 2).

\subsection{Multiculturalism in the Missiology}

This section will explore the Methodist Church's attitude toward the issue of ethnic tolerance. While most European refugees during the early postwar era shared Judeo-Christian traditions, their cultures, of predominantly Eastern European origin, were quite different from American mainstream culture. Sponsoring them, therefore, involved accepting those with different cultures, 
ethnicity, and creeds into the local communities. In addition, a close look at the makeup of the refugees sponsored by Methodists reveals that the majority were not coreligionists. According to an MCOR report, members of the Orthodox faith represented two-thirds of those resettled by MCOR under the DP Acts (MCOR 1954: 11). Methodists accounting for only a small portion of European refugees, less than 5 percent of those assisted through MCOR under the acts were members of this denomination (MCOR 1952b:4). Methodists were also proud that they took 'some mixed marriages, family groups which were not acceptable to the representatives of other sectarian agencies' (1952C: 12). The Methodist Church thus sponsored many people of different creeds and traditions, a policy in line with the MCOR Charter of 1940 that focused on 'the relief of human suffering without distinction of race, color, or creed' (MCOR 1940). An NCC statement of March $195^{2}$ likewise demanded that immigration and naturalization laws be amended so that all discriminatory provisions based upon considerations of color, race or sex would be removed' (NCC 1952: 2).

In the case of refugees who entered the Us under the Refugee Relief Act, 3,087 persons ( 71 percent) out of a total of $4,35^{\circ}$ persons resettled by the MCOR were Protestant. Of the remaining 1,263 persons (29 percent) who were non-Protestant, 489 persons (11.2 percent) were of Catholic faith, 365 (8.4 percent) Orthodox, 270 (6.2 percent) Muslim, 108 (2.5 percent) with no religion, 24 'unclassified' Christian, 4 Buddhist, and 3 Jewish (the last three accounting for less than 1 percent). Furthermore, among the Protestants, only 77 (1.8 percent) were Methodist. The largest Protestant group consisted of 1,231 persons (28.3 percent) who were Lutheran, while the second largest group of 488 (11.2 percent) belonged to the Reformed Church (MCOR 1953b: 11). These figures indicate that Methodists were fairly open to those of other denominations, even other faiths. Warfield reiterated this position as follows:

Christian charity expects us to help the suffering without regard to nationality, race or creed. Men naturally look after their own and in this way Christians are not different. But our hearts must be bigger and our visions wider than others, so that with equal joy we can share with those who are of a different faith. This principle is so generally accepted, at least in theory, that it is not necessary to labor the point further (Warfield 1958:2).

The promotion of tolerance toward other cultures and faiths marked the writings of Elizabeth M. Lee, the Promotion Secretary for MCOR's refugee resettlement program under the Refugee Relief Act. Having formerly served as a missionary to Japan (1915-1924) and also as Executive Secretary for Latin America, of 
the Woman's Division of Christian Service of the Methodist Board of Missions (1940-1954), Lee had warned against ethnocentrism (Lee 1929a: 101, 109; Lee 1929b: 234; Lee 1945: 11; Chiba and Furukawa 2010: 289-290, 299-300, 319-339). After assuming the MCOR position in 1954, she toured many refugee camps in Europe, and presented the resettlement program to the Methodist Church in order to secure assurances of support, by speaking at the Church's area conferences and numerous local churches across the country, and by contributing articles to the church press (MCOR 1956: 5-6; Chiba and Furukawa 2010: 324). For example, in an article for the Methodist Women of September 1954, she wrote:

In the process of welcoming refugees, sponsorship... is not alone a giving process. These liberty-loving people, who have withstood oppression and overcome hardships in slave-labor camps, have something to give us. Aside from being an example of devotion to freedom, they can share with us their European culture (Lee 1954: 9) [Italics mine].

Thus, in addition to seeing the 'liberty-loving' refugees as America's political assets, she described their culture in a positive light, as something that could enrich local culture. In other words, she highlighted the presence of mutuality in the sponsorship of refugees.

In fact, according to Lee, the procurement of sponsorships was delayed partly because too many church people were too 'choosey' about the kind of refugees they would welcome. Thus, in May 1955, writing for World Outlook, another Methodist magazine, she appealed to the readers to sponsor any kind of family that was in need, 'regardless of nationality or religion, regardless of work skill, or number of children, or educational attainments' (Lee 1955b: 227). As she wrote in an article for the Christian Century, a magazine for mainline Protestantism, of February 1955, one prospective sponsor asked for "a Methodist family, either Dutch or Scandinavian," but there were actually "no Methodists in Holland and no refugees in Scandinavia." While it was understandable, she stated, that most Protestant sponsors preferred a Protestant family, they needed to help some Orthodox refugees, for whom the cws carried responsibility. Lee then called out to church members to sponsor any family in need "without prejudice" and without expecting "to meet employment needs or to increase the membership" of their particular church (Lee 1955a: 202-204).

In promoting the need for openness to those of other cultures and faiths, Lee too made good use of the example of the Good Samaritan. She stated: 'The Good Samaritan apparently never stopped to question whether the half-dead pilgrim across the road was of his own race or creed. He just 
went over and bound up his wounds, and brought him into the inn, and paid his bill for that day, and promised he would pay more upon his return' (Lee 1955b: 227). 'Homeless Muslims who seek freedom from persecution in America have a right to expect us Christians to be good Samaritans' (Lee 1955a: 204). Lee thus challenged her readers to surround refugees with Christian good neighborliness, not merely by giving money but by welcoming refugees 'into their communities, their churches, even their homes' (Lee 1955b: 227).

In reality, however, notwithstanding its non-discrimination policy, churches had to act in the framework of government immigration policy and be guided in principle by the limits set by legislations. The immigration quotas for various areas were prescribed by the Refugee Relief Act, and the resulting disproportionate distribution of visas could not be corrected due to the lack of Congressional action (Methodist Program 1953: 2, 8).

Moreover, regarding the integration of refugees into American society, an MCOR report on its resettlement program, which Lee coauthored, affirmed cultural tolerance, by quoting from a report of a UnEsco Conference on Cultural Integration of Immigrants held in Havana in April 1956, as follows:

The American concept of integration is not that of assimilationremoulding the newcomer in everything from clothe to ideology. It is, rather, a long process of mutual give and take, a "cultural differentiation within a framework of social unity," a "moving equilibrium of conformity, varying with time and social conditions" (Methodist Program 1953: 1).

This policy, one of cultural pluralism, was also expressed in a 196o document prepared by cws' Immigration Services, 'Integration: Melting Pot vs. Cultural Pluralism' (cws 1960).

Of course, 'integration' did not always proceed smoothly. There were many prospective sponsors who were 'choosy', and some sponsors did not try to understand refugees' alien customs, to surmount the language barrier, or to help them gently to feel at home in America (Lee 1955b: 6). The experiences of the horror of war and of the hardships of concentration camp-life, shortages of funds and skills, and culture shock surely made many refugees' adjustment difficult. However, as various private (especially, religious) organizations and governmental agencies 'stood ready to assist them', most refugees of this era 'probably experienced fewer problems than had nineteenth-and early twentieth-century immigrants' (Dinnerstein and Reimers 2009: 122-123). It was a time when, in addition to a Cold War climate that made most Americans sympathetic to those who had fled Communism, the churches' humanitarian and multicultural 
beliefs and motivations, backed by the abatement of ethnic conflict and the general prosperity in postwar America, played a significant role in the promotion of the resettlement program (Dinnerstein and Reimers 2009: 116-117).

4

\section{Conclusion}

This paper, with a focus on the Methodist case, has examined how the Protestant church, through its interdenominational network, began its active involvement in postwar refugee resettlement in the us. Despite their initial confusion and inefficiency, the churches made a remarkable contribution to the formation and implementation of the program, setting the pattern for us refugee work in the postwar era. As government and other secular forces expanded their spheres of influence, the churches perceived refugee relief as an area of vital importance in which it had a special mission to demonstrate the power and meaning of the Christian faith by providing personal and spiritual care to refugees. Thus, the church leaders assumed the 'complementarity' of their relief programs to government policies. Sponsorship meant a test to follow the example of the Good Samaritan and a call to good neighborliness.

Historical records of the period reveal that church leaders urged the government to take more persistent action and advocated more liberal refugee laws and fairer, non-discriminatory immigration legislation. Furthermore, by sponsoring a sizable number of refugees of different traditions or faiths, the churches encouraged a multicultural attitude leading to a greater diversity within the American population and to a more pluralistic identity. Though surely not all churches practiced what they preached, the contribution of church policy to the growth of cultural tolerance in the us deserves recognition. ${ }^{7}$

Later, with the coming of non-European refugees, the churches continued to expand their services, maintaining a basic doctrine of non-discrimination. As the areas of the relief program broadened and the sum of government subsidy to the churches increased, however, the church-state partnership grew complicated, and the tension between national security concerns and humanitarian needs have thereafter continued (Nichols 1998: 15-18).

Churches basically shared the anti-Communist framework with the government during the Cold War era, and America's religious morality has often been associated with ethnocentric self-portrait of Americans as a chosen people

7 A recent paper prepared by cws staff (Eby, Smyers and Kekic 2010) reports that most churches in the cws network today 'agree to co-sponsor a refugee family regardless of their religious or ethnic background.' 
and resulting self-righteousness. At the same time, this study points to the churches' post-war role - and hence future potential role-as a contributor to ethnic tolerance and pluralism, instead of a government's collaborator merely accommodating itself to America's narrow national interest. For me, observing these developments from Japan, a country that has largely resisted any major inflows of refugees, this solid basis for voluntary cooperation and multiculturalism deriving from the belief in human brotherhood is notable indeed. ${ }^{8}$ Meanwhile, good neighborliness remains to be a challenge and the key element for successful resettlement work of churches today. It further requires a contextual approach for understanding refugees and meeting their needs, and the repudiation of a condescending attitude toward the newcomers.

\section{Bibliography}

Chiba, Hiromi and Terumi Furukawa, eds. (2010). Misu Daiyamondo to Sera-fuku [Miss Diamond and Sailor-collar School Uniform]. Tokyo: Chuo-koron shinsha.

Church World Service [cws], (1960a). Integration. Melting Pot vs. Cultural Pluralism. cws-Migration Services 1959-1960.

cws (1960b). Practical Casework. The Rediscovery of Old Values. Cws-Migration Services 1959-1960.

cws (1960c). Immigration Services. A Link Between Refugee and Sponsor. 4 February 1960.

cws (196od). A Proposed Letter to the President of the United States. February 4, 1960. cws, Migration Service 1959-1960.

Daniels, Roger (2004). Guarding the Golden Door. New York: Hill and Wang.

Dinnerstein, Leonard (1982). America and the Survivors of the Holocaust. New York: Columbia University Press.

Dinnerstein, Leonard and David M. Reimers (2009). Ethnic Americans. 5th ed., New York: Columbia University Press.

Eby, Jessica, Jenifer Smyers and Erol Kekic (2010). "The Faith Community's Role in Refugee Resettlement and Advocacy in the United States." Paper presented at the conference on faith-based humanitarianism at Oxford University's Refugee Studies Centre, September 2010.

Elias, Julius A. (1953). "Relations Between Voluntary Agencies and International Organizations." Journal of International Affairs 7, 1: 30-34.

8 Japan has limited the number of recognized refugees to a very small number (only a few dozen annually), apart from the 11,00o Indo-Chinese refugees that were accepted between 1979 and 2006. See Iguchi, 2010. 
Holman, Philip A. (1996). "Refugee Resettlement in the United States." In David W.

Haines, ed. Refugees in America in the 199os. Westport CN: Greenwood Press: 3-27.

Genizi, Haim (1993). America's Fair Share. Detroit: Wayne State University Press.

Gordon, Linda W. (1996). "The Origins and Initial Resettlement Patterns of Refugees in the United States." In David W. Haines, ed. Refugees in America in the 199os. Westport CN: Greenwood Press: 331-350.

Iguchi, Yasushi (2010). "Outlook for Refugee Reception through 'Third Country Resettlement'.' Presentation material at International Symposium 'Japan's Refugees Reception System in Transition and Local Community'. Komaba Campus, University of Tokyo, July 3, 2010.

Lee, Elizabeth M. (1929a). “Can The Races Live Together?” Epworth Herald 2 February 1929: 101, 119 .

Lee, Elizabeth M. (1929b). "Who calls us Christian.” Zion's Herald 20 February 1929: 234. Lee, Elizabeth M. (1945). "Do You Know?” Methodist Women October 1945: 11.

Lee, Elizabeth M. (1954). “Will You Open the Door?" Methodist Woman September 1954: 9. Lee, Elizabeth M. (1955a). "These Are the Refugees." Christian Century 16 February 1955: 202-204.

Lee, Elizabeth M. (1955b). “Who Is Your Neighbor?” World Outlook May 1955, 225-227. Lee, Elizabeth M. (1958). “MCOR—What Is It?” Methodist Woman June 1958: 20.

Methodist Committee for Overseas Relief [MCOR], (1940). Charter by MCOR 1940. Policy and Programs 1940-1959.

MCOR (1942). Statement of MCOR, July 24, 1942. Policy and Programs 1940-1959.

MCOR (1943). Report of MCOR to the Board of Education of the Methodist Church,

February 16, 1943. Reports to Agencies, General Conference 1942-1960.

MCOR (1948a). Report of MCOR to General Conference 1948. Reports to Agencies, General Conference 1942-1960.

MCOR (1948b). Statement to the Committee on the Advance for Christ and His Church by MCOR, October 2, 1948. Policy and Programs 1940-1959.

MCOR (1952a). Report of MCOR to the Annual Meeting of the Board of Missions and Church Extension, January 15-19, 1952. Reports to Agencies, General Conference 1942-1960.

MCOR (1952b). Report of the Staff to MCOR, February 13-14, 1952. Staff ReportFebruary 13-14, $195^{2}$.

MCOR (1952c). Report of MCOR to the General Conference of the Methodist Church, April 23, 1952. Reports to Agencies, General Conference 1942-1960. MCOR (1953a). Annual Meeting, February 10-11, 1953. Appendix E: Report of Methodist Migration Service.

MCOR (1953b). Methodist Program under the Refugee Relief Act of 1953.

MCOR (1953C). Minutes of the Special Meeting, September 24, 1953.

MCOR (1954). Annual Meeting, February 2-3, 1954. 
MCOR (1955). Executive Committee Meeting, September 23, 1955.

MCOR (1956). Report of the Director to the Annual Meeting, MCor, January 31, 1956.

MCOR (1957). The Methodist Program under the Refugee Relief Act of 1953 (1957).

Reports to Agencies, General Conference 1942-1960.

MCOR (1958). Report of MCOR to the Annual Meeting of the Board of Missions, January 14-17, 1958. Reports to Agencies, General Conference 1942-196o.

MCOR (1960a). Report of MCOR to the Annual Meeting of the Board of Missions, January 19-22, 1960.

MCOR (196ob). Report of the Secretary for Refugee Resettlement, February 24-25, 1960.

Reports to Agencies, General Conference 1942-1960.

Migration Services Policy Committee [MSPC] (1958). Minutes, January 16, 1958.

Statistical Appendix 5: Refugee Resettlement by Various U.s. Agencies in the Post World War II Period, cWs -Migration Services 1958.

MSCP (1960). Minutes, May 26, 1960. Appendix 4, CWS-Migration Services, 1959-1960.

National Council of the Churches of Christ in America [NCC], (1952). United States

Immigration and Naturalization Policy. Statement Approved by General Board of NCC, March 21, 1952. CWS - Migration Services 1959-1960.

NCC (1957). Proposed Resolution for General Assembly, November 8, 1957. CWsMigration Services 1957.

NCC (1959). General Board of the NCC. Meeting in Detroit, Michigan on December 3, 1959.

Resolution on Refugees and Immigration. Cws - Migration Service 1959-1960.

Nichols, Bruce J. (1998). The Uneasy Alliance. New York: Oxford University Press.

Robert, Dana L. (1997). "From Missions to Mission to Beyond Missions. The Historiography of American Protestant Foreign Missions Since World War II." In Harry S. Stout and Darryl G. Hart, eds. New Directions in American Religious History. New York: Oxford University Press: 367-393.

Schäfer, Axel R. (2006). "Religious Non-Profit Organizations, the Cold War, the State and Resurgent Evangelicalism, 1945-90." In Helen Laville and Hugh Wilford, eds. The US Government, Citizen Groups and the Cold War. New York: Routledge: 175-193.

Smith, Richard F. (1966). "Refugees." The Annals of the American Academy of Political and Social Science 367, 1: 43-52.

United Methodist Committee for Overseas Relief [UMCOR], (2009). History, website UMCOR, http://www.umcor.org/UMCOR/About-Us/History (accessed June 15 2016).

US Displaced Persons Commission [DPC], (1952). Memo to America. The DP Story. Washington: Government Printing Office.

Warfield, Gaither P. (1958). Is the Good Samaritan Outmoded? Mcor Press Release. Wyman, Mark (1998 [1989]). DPs. Europe's Displaced Persons, 1945-1951. Ithaca: Cornell University Press. 
Zucker, Norman L. (1982). "Refugee Resettlement in the United States. The Role of the Voluntary Agencies.” Michigan Yearbook of International Legal Studies. New York: C. Boardman Co: $155^{-177 .}$

All archival documents referred to in this contribution can be found in the Records of United Methodist Committee for Overseas Relief (UMCOR), General Commission on Archives and History, Drew University Campus, Madison NJ. 